\title{
Growth in Mustard and Rapeseed Production: A Zone Wise Analysis in Eastern Uttar Pradesh, India
}

\author{
Ekta Pandey* and V.N. Rai \\ Department of Agricultural Statistics, Narendra Dev University of Agriculture and \\ Technology, Kumarganj-Faizabad (UP), 224-229
}

*Corresponding author

\begin{abstract}
A B S T R A C T
Keywords

Growth functions,

Growth rate,

Instability index,

Trend analysis.

Article Info

Accepted:

06 July 2018

Available Online:

10 August 2018

The paper attempts to study the growth and instability of rapeseed and mustard production in Eastern Uttar Pradesh. The time series data on area, production and productivity of rapeseed and mustard pertaining to the period $1980-81$ to $2014-15$ were used for the study. The study relates to 1980-81 to 2014-15 which is further divided into four sub- periods. The area under rapeseed and mustard has registered positive growth rate in all three zones viz. North Eastern Plain Zone, Eastern Plain Zone and Vindhyan Zone. The area, production and productivity of rapeseed and mustard are found to be highest in Eastern Plain Zone.

\section{Introduction}

Rapeseed and mustard is among the oldest recorded spices as seen in Sanskrit records dating back to about $3000 \mathrm{BC}$ and was one of the first domesticated cops. Originally it was the condiment that was known as mustard and the word was derived from the Latin mustum. Three types of mustard seeds are properly used as condiments: pale yellow or white mustard; brown and oriental mustard; and black or dark brown mustard. Apart from their use as a spice, mustard are widely used as green vegetables, as a salad crop, as an important oil seed crop, green manure or as a fodder crop and for industrial oil purposes. On

an average, India produces around 7.67 million tones of rapeseed and mustard annually (2010-2011). It stands at the $3^{\text {rd }}$ position in the list of rapeseed/ mustard producing countries contributing around $11 \%$ of the world's total production.

\section{Materials and Methods}

\section{Materials}

The time series data on area, production and productivity of rapeseed \& mustard for 35 years from $1980-81$ to $2014-15$ has been collected from the Bulletins of Directorate of Agricultural Statistics and Krishi Bhawan Lucknow, Government of Uttar Pradesh.
\end{abstract}




\section{Methods}

\section{Growth models}

The growth rate in area, production and productivity of rapeseed and mustard have been worked out by fitting the following three different functions:

1) Simple linear function

$$
Y_{t}=a+b_{t}
$$

2) Compound growth rate function

$$
\mathrm{Y}_{\mathrm{t}}=\mathrm{a}(1+\mathrm{r})^{\mathrm{t}}
$$

where, $Y_{t}$ stands for area/ production/ productivity, $\mathrm{t}$ is time index, $\mathrm{a}$ and $\mathrm{b}$ are model parameters, and $\mathrm{r}$ is the compound growth rate.

\section{Measure of instability in oilseed production}

High growth and low instability in production are prerequisites for sustainable agricultural performance. It has been a great concern that technological change in rapeseed and mustard production has increased variability, which is considered to be one of the important facts. Since the magnitude of growth and instability in rapeseed and mustard production has serious implications for policy makers, the level of instability in the area, production and productivity has been estimated by using Cuddy Della Valle Index, which corrects the coefficients of variations and it is given by

Instability index $=\mathrm{cv} \sqrt{1-\mathrm{R}^{2}}$

where, $\mathrm{R}^{2}$ is the coefficient of determination from a time trend regression and $\mathrm{cv}$ is the coefficient of variation.

\section{Results and Discussion}

Trends in area, production and productivity of rapeseed and mustard

The triennium average of area (in thousand hectares), production (thousand tones) and productivity ( $\mathrm{kg} /$ hectare) and its per cent change in different decadal periods for rapeseed and mustard are depicted in the Table 1.

\section{Area}

The triennium average of area and its per cent change in all zones in differential decadal periods. The maximum increase has been found during 1980-81 to 2014-15 in North Eastern Plain Zone. Whereas, production and productivity also has been increased in North Eastern Plain Zone. The increasing trend in the area, production and productivity of rapeseed and mustard is quite low in Vindhyan Zone. The area under mustard has increased at the rate of about 1.14 per cent annually since $1980-81$ to $2014-15$. This increase in growth rate was prominent during the first period 2.41 per cent. In the case of production, it has increased at the rate of about 3.13 per cent annually during the entire period under study.

A high growth rate in the production of mustard has been found 7.40 per cent during first period. Similar in the case of productivity of mustard has also increased at the rate of about 1.98 per cent annually since $1980-81$ onwards. A high growth rate of about 9.23 per cent was observed during first period.

An overall area of mustard has been found quite encouraging in the Eastern Plain Zone. It can be seen from table 2 the area has increased at the rate of 4.73 per cent annually since 1980-81 to 2014-15. This increasing growth rate was distinguished more 11.05 per cent during first period as compared to that of about 1.28 per cent during third period. The production of mustard has increased at the rate of about 7.84 per cent during the entire period under study. A high growth rate in the production has been found 13.64 per cent during first period as compared to the second period i.e. 4.41 per cent. 
Table.1 Triennium averages ending at year shown of area (in '000' ha.), production (in '000' tones) and productivity (in $\mathrm{kg} / \mathrm{ha}$ ) of rapeed and mustard and its changing pattern in North Eastern Plain Zone

\begin{tabular}{|c|c|c|c|c|c|c|c|c|c|c|}
\hline Crops & $1980-81$ & $1990-91$ & $2000-01$ & 2010-11 & $2014-15$ & $\begin{array}{l}\% \text { change } \\
\text { in 1990-91 } \\
\text { over } \\
1980-81\end{array}$ & $\begin{array}{l}\% \text { change } \\
\text { in } 2000-01 \\
\text { over } \\
1990-91\end{array}$ & $\begin{array}{l}\% \text { change } \\
\text { in } 2010-11 \\
\text { over } \\
2000-01\end{array}$ & $\begin{array}{l}\% \text { change } \\
\text { in2014-15 } \\
\text { over } \\
2010-11\end{array}$ & $\begin{array}{l}\% \text { change } \\
\text { in } 2014-15 \\
\text { over } \\
1980-81\end{array}$ \\
\hline Production & 16.63 & 33.96 & 56.03 & 51.39 & 39.31 & 104.18 & 67.98 & -8.27 & 154.46 & 656.92 \\
\hline Productivity & 37.59 & 64.70 & 74.30 & 85.75 & 63.08 & 72.10 & 14.83 & 15.40 & -20.86 & 69.95 \\
\hline
\end{tabular}

Table.2 Triennium averages ending at year shown of area (in '000' ha.), production (in '000' tones) and productivity (in $\mathrm{kg} / \mathrm{ha}$ ) of rapeed and mustard and its changing pattern in Eastern Plain Zone

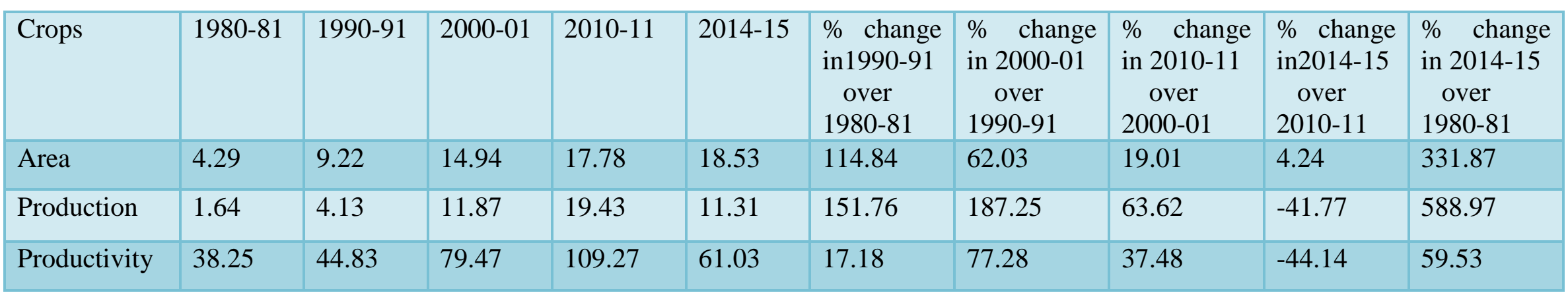


Table.3 Triennium averages ending at year shown of area (in '000' ha.), production (in '000' tones) and productivity (in $\mathrm{kg} / \mathrm{ha}$ ) of rapeed and mustard and its changing pattern in Vindhyan Zone

\begin{tabular}{|c|c|c|c|c|c|c|c|c|c|c|}
\hline Crops & $1980-81$ & $1990-91$ & $2000-01$ & 2010-11 & $2014-15$ & $\begin{array}{l}\% \text { change } \\
\text { in } 1990-91 \\
\text { over } \\
1980-81\end{array}$ & $\begin{array}{l}\% \text { change } \\
\text { in } 2000-01 \\
\text { over } \\
1990-91\end{array}$ & $\begin{array}{l}\% \text { change } \\
\text { in } 2010-11 \\
\text { over } \\
2000-01\end{array}$ & $\begin{array}{l}\% \text { change } \\
\text { in } 2014-15 \\
\text { over } \\
2010-11\end{array}$ & $\begin{array}{l}\% \text { change } \\
\text { in } 2014-15 \\
\text { over } \\
1980-81\end{array}$ \\
\hline Production & 1.52 & 1.77 & 2.33 & 3.25 & 3.17 & 16.44 & 31.63 & 39.48 & -2.46 & 108.55 \\
\hline Productivity & 42.19 & 28.37 & 28.44 & 59.93 & 48.01 & -32.73 & 0.23 & 110.70 & -19.89 & 13.79 \\
\hline
\end{tabular}

Table.4 Annual average simple and compound growth rates of area, production and productivity of Mustard during different periods in North Eastern plain Zone

\begin{tabular}{|l|l|l|l|l|}
\hline Period & & Area & Production & Productivity \\
\hline 1980-81 to 1994-95 & S.G.R & 2.45 & 7.27 & 5.78 \\
\cline { 2 - 5 } & C.G.R & 2.41 & 7.46 & 9.23 \\
\hline 1995-96 to 2004-05 & S.G.R & -0.73 & -0.84 & -0.10 \\
\hline & C.G.R & -0.74 & -0.87 & -0.10 \\
\hline 2005-06 to 2014-15 & S.G.R & 0.39 & -0.96 & -1.30 \\
\hline & C.G.R & 0.39 & -0.94 & -1.31 \\
\hline $1980-81$ to 2014-15 & S.G.R & 1.06 & 2.65 & 1.82 \\
\hline & C.G.R & 1.14 & 3.13 & 1.98 \\
\hline
\end{tabular}


Table.5 Annual average simple and compound growth rates of area, production and productivity of Mustard during different periods during Eastern plain Zone

\begin{tabular}{|l|l|l|l|l|}
\hline Period & & Area & Production & Productivity \\
\hline 1980-81 to 1994-95 & S.G.R & 10.71 & 12.83 & 2.27 \\
\hline & C.G.R & 11.05 & 13.64 & 2.32 \\
\hline 1995-96 to 2004-05 & S.G.R & 0.30 & 4.31 & 3.91 \\
\hline & C.G.R & 0.32 & 4.41 & 3.96 \\
\hline \multirow{2}{*}{ 2005-06 to 2014-15 } & S.G.R & 1.26 & -2.79 & -4.10 \\
\hline \multirow{2}{*}{ 1980-81 to 2014-15 } & C.G.R & 1.28 & -2.84 & -4.07 \\
\hline & S.G.R & 3.74 & 5.73 & 2.79 \\
\hline & C.G.R & 4.73 & 7.84 & 2.96 \\
\hline
\end{tabular}

Table.6 Annual average simple and compound growth rates of area, production and productivity of Mustard during different periods during Vindhyan Zone

\begin{tabular}{|l|l|l|l|l|}
\hline Period & & Area & Production & Productivity \\
\hline $1980-81$ to $1994-95$ & S.G.R & 5.21 & 1.81 & -3.34 \\
\hline & C.G.R & 5.61 & 1.92 & -3.55 \\
\hline 1995-96 to 2004-05 & S.G.R & -1.04 & 1.07 & 2.68 \\
\hline & C.G.R & -1.08 & 1.27 & 2.59 \\
\hline 2005-06 to 2014-15 & S.G.R & 3.66 & 4.84 & 1.14 \\
\hline & C.G.R & 3.67 & 5.02 & 1.20 \\
\hline $1980-81$ to $2014-15$ & S.G.R & 1.03 & 1.78 & 0.62 \\
\hline & C.G.R & 1.24 & 1.88 & 0.60 \\
\hline
\end{tabular}

Table.7 Measures of instability in area, production, and productivity of rapeseed and mustard crop Instability index (in \%) of Mustard during $1980-81$ to $2014-15$

\begin{tabular}{|l|l|l|l|}
\hline Zone & Area & Production & Productivity \\
\hline North Eastern Plain Zone & 8.71 & 13.02 & 8.74 \\
\hline Eastern Plain Zone & 12.25 & 15.49 & 13.05 \\
\hline Vindhyan Zone & 22.87 & 23.24 & 22.69 \\
\hline
\end{tabular}


The productivity of mustard has also increased at the rate of about 2.96 per cent annually since $1980-81$ to $2014-15$. A high growth rate of about 3.96 per cent was observed during third period.

The overall growth rate of area, production and productivity of mustard in Vindhyan Zone increased at the rate of 1.24, 1.88 and 0.60 per cent respectively (Table 3 ). The highest growth rate of area was found during 5.61 per cent during first period. The highest growth rate of production was found 5.02 per cent during third period. The highest growth rate of productivity was found 2.59 per cent during second period as against 1.20 per cent during third period.

High instability has been found in case of area, production and productivity in Vindhyan Zone. It may be observed from the table that the North Eastern Plain Zone has lower instability in area, production and productivity as compared to other zones (Table 4-7).

In conclusion, it can be observed from the results the production of rapeseed and mustard has increased annually 7.84 per cent in Eastern Plain Zone. The per cent area has increased in North Eastern Plain Zone in area, production and productivity. The high growth rate has been found in first period of all zones in Eastern Uttar Pradesh. Therefore, there is need of launching another mission- mode approach by the policy makers at the state and national level to enhance the production of rapeseed and mustard. The farmers are also required to be given facilities and incentives for oilseeds production in general and rapeseed and mustard in particular.

\section{References}

Awaghad, P. R., Ganvir, B. N. and Bhopale, A. A. (2010) Growth and instability of kharif sorghum in Western Vidarbha region. Journal of Soils and Crops, 20: 1, 111-117.

Chandran, K. P., Pandit, A. and Pandey, N. K. (2005). Evaluation of models for estimating potato production trends in major states of India. Potato Journal, 32: 3/4, 219-220.

Kaushik, K.K. (1993), Growth and instability of oilseed production in India. Indian J. Agric. Econ, 48(3), 334-338

Singh, O. P. (2002). An Analysis of Major Oilseed Production in Gujarat, Economic Affairs, Vol. 47(4), 234243.

\section{How to cite this article:}

Ekta Pandey and Rai, V.N. 2018. Growth in Mustard and Rapeseed Production: A Zone Wise Analysis in Eastern Uttar Pradesh, India. Int.J.Curr.Microbiol.App.Sci. 7(08): 763-768. doi: https://doi.org/10.20546/ijcmas.2018.708.084 